\title{
SLOW RUSTING RESISTANCE IN IRANIAN BARLEY CULTIVARS TO PUCCINIA STRIIFORMIS F. SP. HORDEI
}

\author{
Safar Ali Safavi ${ }^{1 *}$, Assadollah Babai Ahari ${ }^{1}$, Farzad Afshari ${ }^{2}$, Mahdi Arzanlou ${ }^{1}$ \\ ${ }^{1}$ Department of Plant Protection, College of Agriculture, University of Tabriz, Tabriz, Iran, P.O. Box: 51666164711 \\ ${ }^{2}$ Department of Cereal Research, Seed and Plant Improvement Institute, Karaj, Iran, P.O. Box: 31585-4119
}

Received: April 10,2012

Accepted: October 15, 2012

\begin{abstract}
Race-specific resistance of barley (Hordeum vulgare L.) to the yellow rust caused by Puccinia striiformis f. sp. hordei, has been reported to be short-lived. Slow rusting resistance has been reported to last for a long time. Twenty Iranian barley cultivars along with resistant and susceptible controls were tested during the 2009-2010 and the 2010-2011 cropping seasons, in field plots at the Ardabil Agricultural Research Station (Iran). The cultivars were tested to identify slow rusting genotypes through epidemiological variables which included: final rust severity (FRS), apparent infection rate (r), relative area under the disease progress curve (rAUDPC), and coefficient of infection (CI). Moreover, differential sets were evaluated in order to determine effective and ineffective resistance genes to barley yellow rust. Results of the mean comparison of resistance parameters showed that cultivars Makouee, Dasht, Fasih, and Arass had low values of FRS, CI, $r$ and rAUDPC compared with susceptible cultivars. The cultivars Walfajre, Abidar and Sahand which had moderate values of the different parameters, were marked as possessing a moderate level of slow rusting. The rest of the cultivars which had high values of different quantitative parameters, were grouped as having a low level of slow rusting or as susceptible. The correlation coefficient between different parameters of slow rusting was significantly high $(\mathrm{r}=0.83-0.98)$. The virulence profile of the prevalent races revealed that $r p s E m 1, r p s E m 2, r p s H F$, Rps4, rpsVa1, rpsVa2, rpsAst were effective, and rps2, Rps1.b were ineffective resistance genes during the two year testing period.
\end{abstract}

Key words: barley, durable resistance, effective genes, slow rusting, yellow (stripe) rust

\section{INTRODUCTION}

Puccinia striiformis Westend., is a species of basidiomycetes fungus causing stripe (yellow) rust on wheat, barley, and many grass species (Wan and Chen 2012). Stripe rust of barley (Hordeum vulgare L.) caused by Puccinia striiformis West. f. sp. hordei, was first separated from other stripe rusts by Eriksson (1894). Barley stripe rust has occurred in Europe and Asia for many years and severe epidemics of the disease have been reported in the north-western and central European countries of India, Bangladesh, Nepal, China, and Japan (Chen et al. 1995). The disease has been a problem in several South American countries since 1975. Yield losses of 30 to $70 \%$ occurred in these regions (Dubin and Stubbs 1986). In California, stripe rust of barley caused yield losses of 15, 20, 15, and 16\% in 1996, 1997, 1998 and 1999, respectively (Chen 2007).

Barley stripe rust was first reported in Iran in 1947 (Esfandiari 1947). Although the disease is not as important as wheat yellow rust, it is increasing in some parts of the northwest and northeast provinces of Iran. An increase in the disease is probably due to cultivation of susceptible cultivars under favorable conditions, or changes of virulence factors in pathogen populations during more recent years (personal data, not published).
The ability to manage disease depends on understanding the composition of pathogen populations. Differentials either have different resistance genes or new gene combinations which provide the information necessary for selection of new sources of host resistance (Brown et al. 2001). Genetic diversity was varied in virulence in the pathogenic fungal populations, and diversity is usually expressed as virulence factors or virulence phenotypes (Brown et al. 2001).

New, more effective fungicides like Tilt, Quadris, Stratego, Headline, and Quilt are available to control yellow rust (Chen 2005). The most efficient, economical, and environmentally friendly approach, though, is to grow resistant cultivars (Line and Chen 1995). Two types of resistance have been identified in several cereal-rust pathosystems; hypersensitive or qualitative (race-specific) and quantitative (race-nonspecific) resistance. Deployment of race-specific resistance genes ensures effective protection against the disease (Shah et al. 2010). This type of resistance, however, is dependent on a specific recognition event between the host ( $\mathrm{R}$ gene products) and the pathogen (Avirulence gene products). The race-specific resistance follows the gene- for- gene interactions, as described by Flor (1956), and may lack durability (Boyd 2005). On the other hand, race-nonspecific resistance is 
mainly polygenic. This type of resistance has often been described as slow rusting or partial resistance (Parlevliet 1979). Race-nonspecific resistance is known to be longlasting and more durable (Herrera-Fossel et al. 2007). Slow rusting is characterized by slow disease progress in the field despite high infection type (Singh et al. 2005). With adult-plant resistance (APR), seedlings are susceptible, but resistance is expressed at post-seedling stages. Adult-plant resistance may be either race-specific or racenonspecific and has been reported in wheat cultivars from regions around the world (Chen et al. 2002). Partial resistance is generally race-nonspecific. This type of resistance results in an early infection, but resistance then develops at the post-seedling stage (Parlevliet 1979). Two types of quantitative resistance, i.e. high temperature adult-plant (HTAP) resistance and slow rusting resistance, have been intensively investigated (Line 2002). In many cereal-rust pathosystems, the quantitative aspects of cultivar resistance have been described and estimated by means of disease severity at a certain crop development stage, the area under the disease progress curve (AUDPC) or by means of apparent infection rate ' $r$ ' and average coefficient of infection (ACI) values for adult plant resistance (Broers et al. 1996; Pathan and Park 2006).

Although several studies have been carried out for assessment of different barley genotypes to yellow rust in Iran (Safavi et al. 2006), no research has been reported on the screening of barley cultivars for slow rusting in Iran. The objectives of the present study were: a) to evaluate barley cultivars for slow rusting resistance and $b$ ) to determine the effective and ineffective resistance genes by evaluating the differential's infection under field conditions.

\section{MATERIALS AND METHODS}

The entire trial was subdivided into two experiments; the differential's infection test that was conducted in field conditions, and another test focused on evaluating slow rusting resistance of commercial barley cultivars.

\section{Field reaction of barley differentials}

The twelve differential barley genotypes used in this study are listed in table 1 . This experiment was carried out under natural conditions at the Ardabil Agricultural Research Station during the 2009-2010 and 2010-2011 time periods. Each entry was planted in two 1 meter rows which were spaced $30 \mathrm{~cm}$ apart. Plots were spaced at $65 \mathrm{~cm}$. The experiment was done in two replications. A susceptible spreader (Afzal) row was sown around the borders of the experiment and 10 entry intervals. All the required cultural practices were carried out during the experiment. Disease severity was estimated according to the modified Cobb's scale; $0 \%$ - immune, and 100\% - fully susceptible (Peterson et al. 1948) when disease was welldeveloped at the flag leaf stage. The infection type (IT) of disease was also recorded based on Roelfs et al. (1992). Effective and ineffective genes were determined based on the studies of Chen and Line (2003). The presence of virulence factors was determined by susceptible infection type while monitoring the disease on differential sets. In other words, corresponding genes against virulence factors of pathogen in plants were considered as ineffective genes and corresponding genes against avirulence factors of pathogen were considered as effective resistance genes. During the 2009-2010 and 2010-2011 crop seasons, seedling reaction of 12 differential sets was also recorded under field conditions, based on a 0 to 9 scale (Line and Qayoum 1992). Race population was considered avirulent on the differential set when there were either no symptoms (IT 0) or there were necrotic or chlorotic flecks (IT 1), necrotic or chlorotic blotches without sporulation (IT 2), or necrotic or chlorotic blotches with only a trace to slight sporulation (IT 3 to 4 ). Race population was considered to be virulent if it caused moderate to abundant sporulation, with or without necrosis or chlorosis (IT $5,6,7,8$, or 9).

\section{Assessment of slow rusting parameters}

The twenty-five barley cultivars used in this study are listed in table 2 . Among the 25 cultivars, 20 were Iranian cultivars along with the susceptible check, and four cultivars (received from Dr. Chen) were: Asterix and Emir as resistant, Topper as susceptible, and Bancroft as a cultivar having HTAP resistance. This experiment was conducted in the Ardabil Agricultural Research Station under natural conditions and artificial inoculation during the 2009-2010 and 2010-2011 cropping seasons. Each entry was planted in two 1 meter rows, spaced $30 \mathrm{~cm}$ apart. Plots were spaced at $65 \mathrm{~cm}$. The experimental design was a randomized complete block design with three replications. Artificial inoculation was carried out with Ardabil races by spraying all test entries and spreader rows once, after sunset, with a mixture of spores and talcum powder (in 1:20 proportions). A susceptible spreader (Torsh) row was sown around the borders of the experiment and 10 entry intervals. Percent severity was recorded three times, starting when Torsh reached 50\% severity according to the modified Cobb's scale (Peterson et al. 1948) and reaction based on Roelfs et al. (1992). The coefficient of infection (CI) was calculated by multiplying disease severity (DS) and constant values of infection type (IT). The constant values for infection types were used based on; resistant $(R)=0.1$, moderately resistant $(M R)=0.25$, moderate or moderately resistant to moderately susceptible $(M)=0.5$, moderately susceptible $(\mathrm{MS})=0.75$, susceptible $(S)=1$ (Pathan and Park 2006). The estimation of the area under the disease progress curve (AUDPC), and the relative area under disease progress curve (rAUDPC) was performed as described by Milus and Line (1986).

Also, the infection rate (r) was estimated in terms of disease severity recorded on barley cultivars at different times (Van der Plank 1968).

The infection rate $(r)$ per unit $(t)$ was calculated as follows:

$$
\mathrm{r}=1 / \mathrm{t}_{2}-\mathrm{t}_{1}\left[\left(\ln \left(\mathrm{x}_{2} / 1-\mathrm{x}_{2}\right)\right)-\left(\ln \left(\mathrm{x}_{1} / 1-\mathrm{x}_{1}\right)\right)\right]
$$

where:

$\mathrm{t}_{1}$ and $\mathrm{t}_{2}$ - dates at which disease severity measurements were made,

$x_{1}$ and $x_{2}$ - the amounts of disease recorded on these dates. 
Then variance of final rust severity (FRS), infection rate $(r)$, coefficient of infection (CI) and rAUDPC was analyzed by MSTAT-c software (a computer based statistical software developed by the crop and Soil Sciences, Department of Michigan State University, USA) (Anonymous 1991). Finally a comparison of cultivars was used to group them based on Duncan's Multiple Range Test (Gomez and Gomez 1984). Seedling reaction of commercial cultivars was also recorded under field conditions based on a 0 to 9 scale (Line and Qayoum 1992) in 2010.

\section{RESULTS AND DISCUSSION}

\section{Variability in differential's infection reaction in field conditions}

Barley yellow rust fungus can change rapidly in virulence. Such a change may overcome resistance in cultivars and result in severe epidemics (Wan and Chen 2012). In order to monitor variations in host-pathogen reaction, differential sets were planted during this study. The results (Table 1) in Ardabil showed that resistance genes rps2, Rps1.b were ineffective. In this study we also concluded that rpsEm1, rpsEm2, rpsHF, Rps4, rpsVa1, rpsVa2, rpsAst were effective resistance genes during the two year period. We decided to considered environmental conditions because sometimes unfavorable conditions (such as high temperature) cause early maturity. Early maturity may provide a crop escape from the disease. Before this study, the results of Safavi et al. (2012) also showed that resistance genes rps2, Rps1.b were ineffective in Ardabil and Mashhad during the 2007-2009 season. In the study of Safavi et al. (2012), it was also concluded that rpsEm1, rpsEm2, rpsHF, Rps4, rpsVa1, rpsVa2, rpsAst were effective resistance genes in different parts of Iran during the 2007-2009 season. Considering the results of the two mentioned studies, we can conclude that during the last five years (from 2007 to 2011), differential sets with resistance genes rpsEm1, rpsEm2, rpsHF, Rps4, rpsVa1, rpsVa2, rps Ast were effective. These genes are race-specific (Chen and Line 2003). In breeding programs the results of this study should be taken into account.

Considering seedling reaction during the 2010 and 2011 season, race populations in Ardabil were virulent on differentials 1, 5, 7, 8, 10, 11, 12 in 2010 and on 1, 5, 7, 9, 10, 11,12 in 2011. The results show little change in race population, i.e. in 2011, the population was virulent on Trumpf but in 2010, virulence was observed on Mazurka. At adult plant stage two, changes were being seen (Table 1). Infection type of Hiproly changed from 10 MS to 30 MSS, and that of Mazurka from R to 30 MS.

Variability in the host reaction could be attributed to the variability in the resistance expression due to pathogen population variability, coupled with variability in climatic conditions (Ali et al. 2009a). Pathogen population diversity, in terms of races, has already been reported across locations in which the locations have different climatic conditions (Chen et al. 2002). It was also reported by $\mathrm{Xi}$ et al. (2003), that scald reactions of the commercial cultivars depends on variation in environmental conditions, and location which reflects the presence of different pathotypes. Similarly, the epidemiological components of P. striiformis f. sp. tritici are known to be affected by both temperature and light (de Vallavieille-Pope et al. 1995).

In terms of Bancroft infection type at seedling and adult plant stage, it is clear that the cultivar has high temperature adult plant (HTAP) resistance which is a kind of durable resistance (Line 2002). Thus, in breeding programs, we can use this cultivar in combination with cultivars having desirable characteristics and other durable resistance genes. Seedlings of cultivars with only HTAP resistance are susceptible to all races of yellow rust at both low and high temperatures. Adult-plants of HTAP resistant cultivars are susceptible at low temperatures, but resistant at high temperatures (Chen 2007). Races with a narrow spectrum of virulence may have advantages in aggressiveness over those with a wide spectrum of virulence on susceptible cultivars or cultivars with a moderate level of race-nonspecific HTAP resistance, such as the cv. Baronesse; the most widely grown cultivar in California (Chen 2007).

It is necessary to continually conduct trap nursery studies, using differential sets and isogenic lines, as one of the tools for population study. By means of these studies, we can get information about population variation from which we can design breeding programs. Effectiveness of breeding is highly dependent on the relevance of information concerning the nature and extent of pathogenic variation. Thus, the results of this study show that breeding programs should be set up.

\section{Slow rusting of barley genotypes}

Different parameters used as criteria to identify genotypes with slow rusting resistance under field conditions included CI, rAUDPC, FRS, and infection rate.

\section{Coefficient of infection (CI) value}

The data on disease severity and host reaction were combined to calculate the coefficient of infection (CI). According to Ali et al. (2007) cultivars/lines with CI values of $0-20,21-40$, and 41-60 were regarded as possessing high, moderate, and low levels of slow rusting resistance, respectively. The cultivars Makouee, Dasht, Arass, Fasih, Emir, Asterix and Bancroft were grouped in the first category. Rihane, Walfajre, Karron, Abidar, Sahand were marked as having a moderate level of slow rusting. Sina, Shirin, Bahman, Zarjow, Torkaman, Jonob and Yoosef were designated as having a low level of slow rusting. Kavir, Eram, Afzal, Goharjow along with Topper and Torsh, exhibited a CI value greater than 60 , and were grouped as susceptible.

Disease pressure was considerably high as indicated by the CI of the susceptible check (Table 2). Maximum CI recorded among tested cultivars was $60-86 \%$ of the susceptible check for five cultivars (i.e. Kavir, Eram, Topper, Afzal, Goharjow), while the remaining 19 cultivars were up to $59 \%$ of the susceptible check. Based on the results, common pathotypes of barley yellow rust in Ardabil were considered virulent on most evaluated cultivars (Table 2). According to the results of other researchers (Johnson 1988; Ali et al. 2007), and in terms of the reaction of the seedling and the adult plant stages in this 
Table 1. Variability in differential's infection reaction in field conditions, in Ardabil, during the 2009-2010 and 2010-2011 cropping seasons

\begin{tabular}{|c|c|c|c|c|c|c|}
\hline \multirow[b]{2}{*}{ No. } & \multirow[b]{2}{*}{ differential sets } & \multirow[b]{2}{*}{ resistance genes ${ }^{a}$} & \multicolumn{2}{|c|}{ Seedling reaction ${ }^{\mathrm{b}}$} & \multicolumn{2}{|c|}{$\begin{array}{l}\text { Severity and infection type at the } \\
\text { adult plant stage }{ }^{c}\end{array}$} \\
\hline & & & 2010 & 2011 & 2010 & 2011 \\
\hline 1 & Topper & - & 7 & 8 & $60 S$ & $80 \mathrm{~S}$ \\
\hline 2 & Helis Franken & $\operatorname{Rps} 4(Y r 4), r p s H F$ & 2 & 2 & TMR & $\mathrm{R}$ \\
\hline 3 & Emir & $r p s E m 1, r p s E m 2$ & 2 & 2 & TMR & $\mathrm{R}$ \\
\hline 4 & Asterix & $R p s 4(Y r 4), r p s A s t$ & 4 & 2 & TMR & TMR \\
\hline 5 & Hiproly & rpsHi1, rpsHi2 & 7 & 7 & $10 \mathrm{MS}$ & 30 MSS \\
\hline 6 & Varunda & rpsVa1,rpsVa2 & 2 & 2 & TMR & $\mathrm{R}$ \\
\hline 7 & Abed Binder & rps2 (yr2) & 7 & 8 & $30 \mathrm{~S}$ & $50 \mathrm{~S}$ \\
\hline 8 & Trumpf & $r p s \operatorname{Tr} 1, r p s \operatorname{Tr} 2$ & 6 & 2 & $10 \mathrm{MR}$ & TMR \\
\hline 9 & Mazurka & Rps1.c & 3 & 6 & $\mathrm{R}$ & $30 \mathrm{MS}$ \\
\hline 10 & Bigo & Rps1.b (yr) & 7 & 7 & $30 \mathrm{~S}$ & $40 \mathrm{~S}$ \\
\hline 11 & I5 & Rps3 (yr3), rpsI5 & 7 & 7 & $30 \mathrm{MS}$ & $30 \mathrm{MS}$ \\
\hline 12 & Bancroft & not determined & 7 & 7 & $20 \mathrm{MS}$ & $30 \mathrm{MS}$ \\
\hline The check & Afzal & - & 8 & 9 & $70 \mathrm{~S}$ & $90 \mathrm{~S}$ \\
\hline
\end{tabular}

adentified by Chen and Line (2003)

bInfection type based on Line and Qayoum (1992)

Infection types based on Roelfs et al. (1992); TMR - trace moderately resistant, R - resistant without sporulation, MR - moderately resistant; small pustules surrounded by necrotic areas, MS - moderately susceptible; medium-sized pustules, no necrosis, but some chlorosis possible, MSS - moderately susceptible to susceptible; medium to large sized pustules without chlorosis or necrosis,

$\mathrm{S}$ - susceptible; large pustules, no necrosis or chlorosis

Table 2. Seedling infection type, mean final rust severity (FRS) when the most susceptible cultivar reached its maximum severity, relative mean area under disease progress curve (rAUDPC), mean infection rate (r) and coefficients of infection (CI) in the two year period, of 24 barley cultivars along with the susceptible control when infected by Puccinia striiformis f. sp. hordei

\begin{tabular}{|c|c|c|c|c|c|c|}
\hline \multirow[b]{2}{*}{ No. } & \multirow[b]{2}{*}{ cultivars } & \multirow[b]{2}{*}{ seedling reaction ${ }^{b}$} & \multicolumn{4}{|c|}{ Values of field-based slow rusting parameters ${ }^{a}$} \\
\hline & & & rAUDPC & $\mathrm{CI}$ & FRS & $\mathrm{r}$ \\
\hline 1 & 2 & 3 & 4 & 5 & 6 & 8 \\
\hline 1 & Emir & 2 & $1.1 \mathrm{n}$ & $0.1 \mathrm{k}$ & $1.0 \mathrm{~m}$ & $0.000 \mathrm{i}(0)^{*}$ \\
\hline 2 & Asterix & 2 & $1.3 \mathrm{n}$ & $0.2 \mathrm{k}$ & $1.3 \mathrm{~m}$ & 0.005 hi $(2.2)$ \\
\hline 3 & Makouee & 2 & $11.8 \mathrm{~m}$ & $3.9 \mathrm{jk}$ & 12.51 & $0.018 \mathrm{~h}(8.1)$ \\
\hline 4 & Dasht & 5 & $26.2 \mathrm{k}$ & $15.4 \mathrm{ij}$ & $29.1 \mathrm{j}$ & $0.053 \mathrm{~g}(24)$ \\
\hline 5 & Arass & 4 & $28.1 \mathrm{jk}$ & $16.6 \mathrm{ij}$ & $31.6 \mathrm{j}$ & $0.056 \mathrm{~g}(25.5)$ \\
\hline 6 & Bancroft & 7 & $16.2 \mathrm{~lm}$ & $15.8 \mathrm{ij}$ & $19.0 \mathrm{kl}$ & $0.056 \mathrm{~g}(25.5)$ \\
\hline 7 & Fasih & 6 & $23.0 \mathrm{kl}$ & $15.2 \mathrm{ij}$ & $28.3 \mathrm{gk}$ & $0.061 \mathrm{~g}(27.7)$ \\
\hline 8 & Walfajre & 8 & $36.1 \mathrm{ij}$ & $27.4 \mathrm{hi}$ & $44.1 \mathrm{i}$ & 0.086 e (39) \\
\hline 9 & Sahand & 7 & $38.2 \mathrm{hi}$ & $29.9 \mathrm{gh}$ & $43.3 \mathrm{i}$ & $0.065 \mathrm{~g}(29.5)$ \\
\hline 10 & Abidar & 7 & $38.9 \mathrm{hi}$ & $32.28 \mathrm{fgh}$ & $44.1 \mathrm{i}$ & $0.070 \mathrm{fg}(31.8)$ \\
\hline 11 & Rihane & 7 & $42.1 \mathrm{jhi}$ & $38.2 \mathrm{efgh}$ & $50.0 \mathrm{hi}$ & 0.085 ef (38.6) \\
\hline 12 & Karron & 8 & $52.7 \mathrm{ef}$ & 39.8 efgh & 60.0 efgh & 0.085 ef (38.6) \\
\hline 13 & Yousef & $6-7$ & 40.3 ghi & 40.6 efg & $50.8 \mathrm{hi}$ & 0.095 e (43.1) \\
\hline 14 & Jonob & 8 & $45.4 \mathrm{fgh}$ & $40.8 \mathrm{efg}$ & 52.5 ghi & 0.093 e (42.2) \\
\hline 15 & Shirin & 7 & $59.2 \mathrm{de}$ & $42.6 \mathrm{efg}$ & 61.6 defg & $0.068 \mathrm{~g}(30.9)$ \\
\hline 16 & Torkaman & 8 & $49.0 \mathrm{fg}$ & $44.1 \mathrm{ef}$ & $58.3 \mathrm{fgh}$ & 0.095 e (43.2) \\
\hline 17 & Zarjow & 7 & $52.1 \mathrm{ef}$ & $48.8 \mathrm{de}$ & $59.1 \mathrm{efghf}$ & 0.098 de (44.5) \\
\hline
\end{tabular}




\begin{tabular}{|c|c|c|c|c|c|c|}
\hline 1 & 2 & 3 & 4 & 5 & 6 & 8 \\
\hline 18 & Bahman & $6-7$ & $52.3 \mathrm{ef}$ & 50.8 de & $58.3 \mathrm{fgh}$ & 0.088 e $(40)$ \\
\hline 19 & Sina & 8 & $62.4 \mathrm{~d}$ & $59.1 \mathrm{~cd}$ & $70.8 \mathrm{~cd}$ & 0.121 с (55) \\
\hline 20 & Kavir & 7 & $59.8 \mathrm{de}$ & $60.1 \mathrm{~cd}$ & 69.1 cde & $0.113 \mathrm{~cd}(51.4)$ \\
\hline 21 & Eram & 8 & $72.3 \mathrm{c}$ & $63.8 \mathrm{c}$ & $75.0 \mathrm{c}$ & 0.121 c (55) \\
\hline 22 & Topper & 8 & $45.2 \mathrm{fgh}$ & $64.1 \mathrm{c}$ & $64.1 \mathrm{def}$ & $0.163 \mathrm{~b}(74)$ \\
\hline 23 & Afzal & 9 & $66.1 \mathrm{~cd}$ & $78.3 \mathrm{~b}$ & $78.3 \mathrm{c}$ & 0.165 b (75) \\
\hline 24 & Goharjow & 9 & $82.9 \mathrm{~b}$ & $86.5 \mathrm{~b}$ & $88.3 \mathrm{~b}$ & 0.165 b (75) \\
\hline 25 & Torsh (the check) & 9 & $100 \mathrm{a}$ & $100.0 \mathrm{a}$ & $100.0 \mathrm{a}$ & $0.22 \mathrm{a}(100)$ \\
\hline
\end{tabular}

a means followed by the same letters in each column are not statistically significant at a $1 \%$ level

binfection type based on Line and Qayoum (1992)

*values in the parenthesis are relative values of the susceptible control Torsh for infection rate

study, the cultivars Makouee, Dasht and Arass may carry race-specific resistance genes or a combination of racespecific resistance genes, which are effective against all virulences used. It is important to note, that cultivars with race-specific resistance often become susceptible within a few years after their release. This is because of the rapid evolution of new virulent races of the pathogens (Wan and Chen 2012). For this reason, the cultivars Makouee, Dasht, Arass, and Fasih, need further inheritance studies or need marker-assisted identification of resistance. The cultivars which had MS or MR infection type may carry durable resistance genes (Brown et al. 2001; Singh et al. 2005). Consequently, cultivars with a low level CI and other quantitative resistance parameters will most probably have partial resistance genes, such as HTAP and slow rusting, and their resistance can last for a long time. Since this kind of resistance is controlled by more than one gene, it is called oligogenic or polygenic (Dehghani and Moghaddam 2004).

The cultivars/lines with a different level of slow rusting resistance are advocated to be more durable (Singh et al. 2004). Cultivars/lines with an acceptable degree of slow rusting, reduce the epidemic development rate and do not directly influence the evolution of races (except when considering demography). These cultivars/lines are, however, controlled by several minor genes; to overcome them in the field will take longer. There are rusts fungi which have more potential to change by different events such as mutation, migration in long-distances, and selection pressure of cultivar genotypes on pathogen genotypes (Hovmoller 2001; Ben Yehuda et al. 2004). With regard to these potential to change, researchers should deploy race-nonspecific or a combination of race-nonspecific with race-specific resistance instead of using only race-specific.

\section{rAUDPC value}

Based on the rAUDPC values, commercial barley cultivars were categorized into two distinct groups according to Ali et al. (2007). One group included the genotypes exhibiting rAUDPC values up to $30 \%$ of the check, and the other included the cultivars showing rAUDPC values up to $70 \%$ of the check. In these cultivars, rust initiated and sporulated but with final chlorotic and necrotic strips (MR and/or MS infection types). Subsequently, the progress of rust development remained slower and restricted.
The cultivars in group 1 were marked as having better slow rusting and that of group 2 were marked as having moderately slow rusting. The reasons for the markings were because they also developed epiphytotic of very low potential as indicated by their rAUDPC values, despite the ultimate expression of high infection type. Cultivars with such traits are expected to possess genes that confer partial resistance (Parlevliet 1988). Makouee, Dasht, Arass, Fasih, Emir, Asterix and Bancroft exhibited rAUDPC values less than $30 \%$ of Torsh and were marked as having better slow rusting. Except for Eram and Goharjow, the rest of the cultivars having rAUDPC values up to $70 \%$ of the susceptible check were grouped as moderately slow rusting in group 2. Topper is unusual in group 2. Its reaction is susceptible, but because of late maturity, it has low values of rAUDPC. In the cv. Topper, the first symptoms start later than in the other cultivars. At final disease recording, this cultivar has a green leaf area for yellow rust development. Both group 1 and 2 were composed of cultivars with varying degrees of slow rusting. These cultivars were advocated to be more durable (Singh et al. 2004). Moreover, cultivars with acceptable levels of slow rusting restrict the evolution of new virulent races of the pathogen. This is because multiple point mutations are extremely rare in nature (Ali et al. 2007). None of the tested cultivars was marked as immune.

\section{Final rust severity (FRS)}

Data on the final rust severity of the 24 cultivars along with the susceptible check (Torsh) are shown in table 2. High disease pressure was recorded at the testing site as maximum FRS - up to $100 \%$ for Torsh, followed by Goharjow (88.3\%), Afzal (78.3\%), and Eram (75\%) classified as susceptible. None of the Iranian cultivars were recorded to be immune. Similarly based on FRS, the tested cultivars were grouped into three groups of slow rusting resistance, i.e. high, moderate, and low levels of slow rusting having: $1-30 \%, 31-50 \%$, and $51-70 \%$ FRS, respectively. Cultivars Makouee, Dasht, Arass, Fasih, Emir, Asterix and Bancroft were included in the first group. Rihane, Walfajre, Abidar, Sahand were marked as having a moderate level of partial resistance. Sina, Shirin, Bahman, Zarjow, Torkaman, Jonob and Yoosef were designated as having a low level of slow rusting. Broers et al. (1996) and Ali et al. (2009b) also carried out field assessment of quantitative resistance to yellow rust for ranking 
the lines. According to the resistance level based on disease severity along with other slow rusting parameters, they found that resistance level ranged from very low to very high among the tested lines.

\section{Apparent infection rate $(r)$}

Infection rate of all cultivars was less than Torsh during the 2010-2011 season. Apart from Torsh, the highest mean $r$-value of 0.165 was recorded for Goharjow and Afzal followed by Topper $(\mathrm{r}=0.163)$ belonging to the susceptible group based on CI, FRS, and rAUDPC values. Similarly, Ali et al. (2008) and Sandoval-Islas et al. (2007), and our present study demonstrated that infection rate seemed an unreliable estimate of slow rusting resistance when compared with FRS, CI, and rAUDPC. The reason for this is because infection rate did not mark some cultivars as having a moderate and a low level of slow rusting. This was seen in such cultivars as Sahand $(r=0.065)$ and Sina (0.121), respectively. In this study, cultivars marked as having a better level of slow rusting (in terms of other slow rusting parameters) indicated an infection rate of less than 0.057. Cultivars with moderate level slow rusting, with regard to other parameters, had an infection rate ranging from 0.065 to 0.086 .

\section{Correlation between the slow rusting parameters for barley yellow rust}

In this study, an attempt was made to elucidate the relationship between field-based slow rusting parameters. A positive relation of the coefficient of infection was found with final rust severity, rAUDPC, and infection rate with strong $\mathrm{r}^{-}$values of 96,94 , and $90 \%$, respectively (Table 3).

Table 3. Linear correlation coefficients between slow rusting parameters for yellow rust across twenty-five cultivars over two years in Ardabil

\begin{tabular}{lccc}
\hline \multirow{2}{*}{ Parameters } & \multicolumn{3}{c}{ Parameters } \\
\cline { 2 - 4 } & CI & rAUDPC & FRS \\
\hline rAUDPC & $0.94^{* *}$ & - & - \\
FRS & $0.96^{* *}$ & $0.98^{* *}$ & - \\
$\mathrm{r}$ & $0.90^{* *}$ & $0.83^{* *}$ & $0.87^{* *}$ \\
\hline
\end{tabular}

FRS - final rust severity

rAUDPC - relative area under disease progress curve

$\mathrm{r}$ - apparent infection rate

$\mathrm{CI}$ - coefficients of infection

** significant at $\mathrm{p}=0.01$ levels of probability

The highest correlation coefficient was between rAUDPC and final rust severity $(r=0.98)$. The lowest $\mathrm{r}^{-}$value was between rAUDPC and infection rate $(r$ $=0.83$ ). This positive correlation was in agreement with the results of other researchers on cereal-rust pathosystems (Sandoval-Islas et al. 2007; Safavi et al. 2010; Shah et al. 2010). Previously, Sandoval-Islas et al. (2007) found good correlation of rAUDPC with quantitative resistance components, i.e. latent period and infection frequency. Field selection of the slow rusting trait preferably by low rAUDPC and terminal ratings along with $\mathrm{CI}$, is feasible where greenhouse facilities are inadequate (Singh et al. 2007). Ochoa and Parlevliet (2007) also found a high correlation coefficient between rAUDPC and yield losses. Since all disease parameters strongly and positively were correlated in the present study, it can be concluded that FRS and CI are the most appropriate parameters. Cultivars identified with slow rusting resistance should be improved/developed further by accumulating 4-5 minor genes to achieve near-immunity prior to deployment as a control strategy for controlling the yellow rust problem.

\section{CONCLUSION}

The results of the current study showed that cultivars had a diversity of resistance, ranging from complete resistance to susceptible. Most of the evaluated cultivars exhibited moderate or low performance under high disease pressure shown by the susceptible check. Resistance of all categories (including complete resistance, to partial resistance) to yellow rust was observed. Cultivars Makouee, Dasht, Fasih, Arass, Abidar and Sahand are supposed to have genes for varying degrees of slow rusting or HTAP. These cultivars can be used for future manipulation in barley improvement programs, after confirmatory studies have been done. However, these cultivars should be assessed for yellow rust as well as for desirable characters, over several years and locations, before approval. Marker-assisted selection could be applied to make the task easier.

\section{ACKNOWLEDGEMENTS}

We would like to thank Dr. Xianming Chen and Dr. Steffenson for providing and sending differential sets. The financial support from SPII (the Seed and Plant Improvement Institute) and the Agriculture and Natural Resources Research Center of Ardabil is highly appreciated.

\section{REFERENCES}

Ali S., Raman H., Shah S.J.A., Alishah S.M., Ullah F. 2009a. Assessment of field resistance using host-pathogen interaction phenotype for wheat yellow rust. Afric. Crop Sci. J. 17 (4): 213-221.

Ali S., Shah S.J.A., Khalil I.H., Raman H., Maqbool K., Ullah W. 2009b. Partial resistance to yellow rust in introduced winter wheat germplasm at the north of Pakistan. Aust. J. Crop Sci. 3 (1): 37-43.

Ali S., Shah S.J.A., Maqbool K. 2008. Field-based assessment of partial resistance to yellow rust in wheat germplasm. J. Agric. Rural Dev. 6 (1): 99-106.

Ali S., Shah S.J.A., Ibrahim M. 2007. Assessment of wheat breeding lines for slow yellow rusting (Puccinia striiformis West. tritici). Pak. J. Biol. Sci. 10 (19): 3440-3444.

Anonymous. 1991. MSTATC Users Guide. East Lansing, MI, USA, Michigan State University, 59 pp.

Ben Yehuda P., Eilam T., Manisterski J., Shimoni A., Akster, Y. 2004. Leaf rust on Aegilops speltoides caused by a new forma specialis of Puccinia triticina. Phytopathology 94 (1): 94-101.

Boyd L.A. 2005. Centenary review: can Robigus defeat an old enemy? - Yellow rust of wheat. J. Agric. Sci. 143 (4): 233-243. 
Broers L.H.M., Cuesta-Subias X., Lopez-Atilano R.M. 1996 Field assessment of quantitative resistance to yellow rust in ten spring bread wheat cultivars. Euphytica 90 (1): 9-16.

Brown W.M.J., Hill J.P., Velasco V.R. 2001 Barley yellow rust in North America. Annu. Rev. Phytopathol. 39 (1): 367-384.

Chen X.M. 2005. Epidemiology and control of stripe rust (Puccinia striiformis f. sp. tritici) on wheat. Can. J. Plant Pathol. 27 (3): 314-337.

Chen X.M. 2007. Challenges and solutions for stripe rust control in the United States. Aust. J. Agric. Res. 58 (6): 648-655.

Chen X.M., Line R.F. 2003. Identification of genes for resistance to Puccinia striiformis f. sp. hordei in 18 barley genotypes. Euphytica 129 (1): 127-145.

Chen X.M., Moore M., Milus E.A., Long D.L., Line R.F., Marshall D., Jackson L. 2002. Wheat stripe rust epidemics and races of Puccinia striiformis f. sp. tritici in the United States in 2000. Plant Dis. 86 (1): 39-46.

Chen X.M., Line R.F., Leung H. 1995. Virulence and polymorphic DNA relationships of Puccinia striiformis f. sp. hordei to other rusts. Phytopathology 85 (11): 1335-1342.

de Vallavieille-Pope C., Huber L., Leconte M., Goyeau H. 1995. Comparative effects of temperature and interrupted wet periods on germination, penetration, and infection of $\mathrm{Puc}$ cinia recondita $\mathrm{f}$. sp. tritici and $P$. striiformis on wheat seedlings. Phytopathology 85 (4): 409-415.

Dehghani H., Moghaddam M. 2004. Genetic analysis of latent period of stripe rust in wheat seedlings. J. Phytopathol. 152 (6): 325-330.

Dubin H.J., Stubbs R.W.1986. Epidemic spread of barley stripe rust in South America. Plant Dis. 70 (2): 141-144.

Eriksson J. 1894. Uber die Spezialisierung des Parasitismus bei den Getreiderostpilzen. Ber. Dtsch. Bot. Ges. 12: 292-331.

Esfandiari E. 1947. Les rouilles de cereales en Iran. Entomologie Phytopath. Appl. 4: 67-76.

Flor H.H. 1956. The complementary genetic systems in flax and flax rust. Adv. Gen. 8 (1): 29-54.

Gomez K.A., Gomez A.A. 1984. Statistical Procedures for Agricultural Research. New York, Wiley, 680 pp.

Herrera-Fossel S.A., Singh R.P., Huerta-Espino J., Crossa J., Djurle A., Yuen J. 2007. Evaluation of slow rusting resistance components to leaf rust in CIMMYT durum wheats. Euphytica 155: 361-369.

Hovmoller M.S. 2001. Disease severity and pathothype dynamics of Puccinia striiformis f. sp. tritici in Denmark. Plant Pathol. 50 (2): 181-189.

Johnson R. 1988. Durable resistance to yellow (stripe) rust in wheat and its implications in plant breeding. p. 63-75. In: “Breeding Strategies for Resistance to the Rusts of Wheat" (N.W. Simmonds, S. Rajaram, ed.). Mexico, CIMMYT, 151 pp.

Line R., Qayoum A. 1992. Virulence, Aggressiveness, Evolution, and Distribution of Races of Puccinia striiformis (the Cause of Stripe Rust of Wheat) in North America, 1968-87. USDA-ARS Tech. Bull., 1788 pp.

Line R.F. 2002. Stripe rust of wheat and barley in North America: A retrospective historical review. Annu. Rev. Phytopathol. 40 (1): 75-118.

Line R.F., Chen X.M. 1995. Success in breeding for and managing durable resistance to wheat rusts. Plant Dis.79 (12): 1254-1255.

Milus E.A., Line R.F. 1986. Gene action for inheritance of durable, high - temperature, adult plant resistances to stripe rust in wheat. Phytopathology 76 (4): 435-441.
Ochoa J., Parlevliet J.E. 2007. Effect of partial resistance to barley leaf rust, Puccinia hordei, on the yield three barley cultivars. Euphytica 153 (3): 309-312.

Parlevliet J.E. 1988. Strategies for the utilization of partial resistance for the control of cereal rust. p. 48-62. In: "Breeding Strategies for Resistance to the Rusts of Wheat" (N.W. Simmonds, S. Rajaram, eds.). Mexico, CIMMYT, 151 pp.

Parlevliet J.E. 1979. Components of resistance that reduce the rate of epidemic development. Annu. Rev. Phytopathol. 17 (1): 203-222.

Pathan A.K., Park R.F. 2006. Evaluation of seedling and adult plant resistance to leaf rust in European wheat cultivars. Euphytica 149 (3): 327-342.

Peterson R.F., Campbell A.B., Hannah A.E. 1948. A diagrammatic scale for estimating rust intensity of leaves and stems of cereals. Can. J. Res. Sect. 26C (5): 496-500.

Roelfs A.P., Singh R.P., Saari E.E. 1992. Rust diseases of wheat: Concepts and Methods of Diseases Management. Mexico, CIMMYT, 81 pp.

Safavi S.A., Atahussaini S.M., Ebrahimnejad S. 2012. Effective and ineffective resistance genes and resistance reaction of promising barley lines to Puccinia striiformis f. sp. hordei in Iran. Asian J. Plant Sci. 11 (1): 52-57.

Safavi S.A., Torabi M. 2006. Study on resistance reaction of elite barley lines to Puccinia striiformis f. sp. hordei in Ardabil. p. 36-37. In: Proc. 3rd regional yellow rust conference. Tashkent, Uzbekistan June 8-11 2006, 66 pp.

Safavi S.A., Ahari A.B., Afshari F., Arzanlou M. 2010. Slow rusting resistance in 19 promising wheat lines to yellow rust in Ardabil, Iran. Pak. J. Biol. Sci. 13 (5): 240-244.

Sandoval-Islas J.S., Broers L.H.M., Mora-Aguilera G., Parlevliet J.E., Osada K.S., Vivar H.E. 2007. Quatitative resistance and its components in 16 barley cultivars to yellow rust, Puccinia striiformis f. sp. hordei. Euphytica 153 (3): 295-308.

Shah S.J.A., Muhmmad M., Hussain S. 2010. Phenotypic and molecular characterization of wheat for slow rusting resistance against Puccinia striiformis Westend. f. sp. tritici. J. Phytopathol. 158 (6): 393-402.

Singh D., Park R.F., McIntosh R.A. 2007. Characterization of wheat leaf rust resistance gene Lr34 in Australian wheats using components of resistance and the molecular marker csLV34. Aust. J. Agric. Res. 58 (11): 1106-1114.

Singh R.P., Huerta-Espino J., William H.M. 2005. Genetics and breeding for durable resistance to leaf and stripe rusts in wheat. Turk. J. Agric. For. 29 (2): 121-127.

Singh R.P., William H.M., Huerta-Espino J., Rosewame G. 2004. Wheat rust in Asia: meeting the challenges with old and new technologies. New directions for a diverse planet. In: Proc. 4th International Crop Science Congress. Brisbane, Australia, 26 Sep.-1 Oct., 2004. www.cropscience.org.au.

van der Plank J.E. 1968. Disease Resistance in Plants. New York, Academic Press, p. 206.

Wan A.M, Chen X.M. 2012. Virulence, frequency, and distribution of races of Puccinia striiformis f. sp. tritici and Puccinia striiformis f. sp. hordei identified in the United States in 2008 and 2009. Plant Dis. 96 (1): 67-74.

Xi K., Turkington T.k., Helm J.H., Briggs K.G., Tewari J.P., Ferguson T. Kharbanda P.D. 2003. Distribution of pathotypes of Rhynchosporium secalis and cultivar reaction on barley in Alberta. Plant Dis. 87 (4): 391-396. 